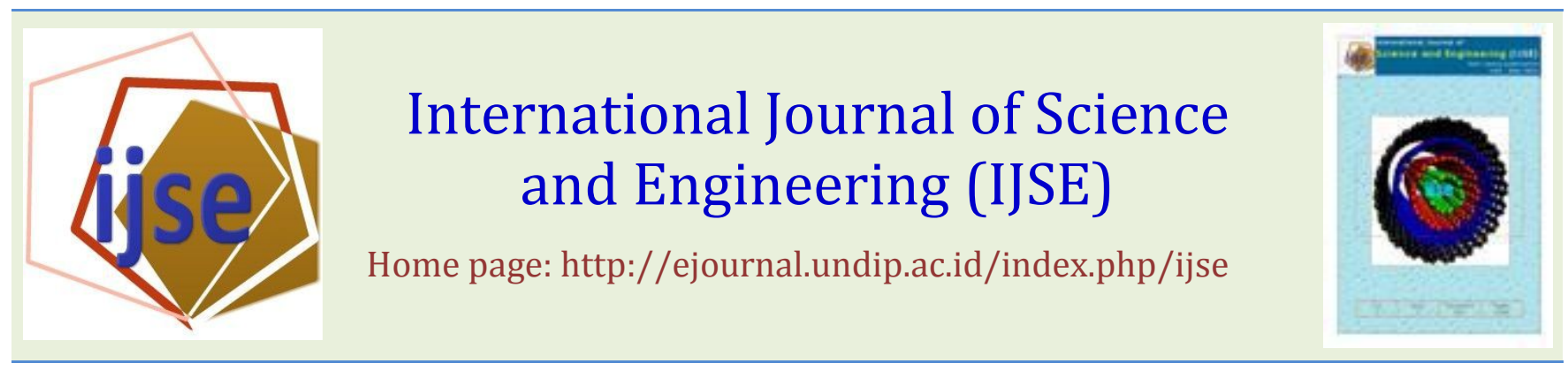

\title{
Environmental Impact Assessment of a Flood Control Channel in Sfax City, Tunisia
}

\author{
Noura Dahri 1,3, Abdelfatta Atoui² and Habib Abida1,3 \\ ${ }^{1}$ Geology Department, Faculty of Science, Sfax University - Tunisia \\ ${ }^{2}$ The regional Management of Sfax Urban Hydraulics - Tunisia \\ ${ }^{3}$ Hydro-sciences Appliqué Research Centre - Gabès University - Gabès - Tunisia \\ dahri.noura@gmail.com,abdelfattah.atoui@gmail.com,habib.abida@voila.fr
}

\begin{abstract}
The objective of this study is to evaluate water and sediment quality in the southern branch of a flood control channel in Sfax city, as well as its neighboring sites. This artificial channel, located $4 \mathrm{~km}$ away from downtown Sfax, was implemented in 1984 to protect the city against floods. Even though it contributed to reduce the harmful flood effects, this channel also resulted in new environmental problems that may cause a public health threat. Indeed, artificial surfaces pose a greater risk of infection due to bacteria, fungi and other microorganisms. A total of 19 water samples (9 from the channel and 10 from groundwater wells) were collected in a dry period and analyzed in the laboratory. Furthermore, 12 sediment samples were taken from the bottom of the channel. Water quality data were used to examine the spatial variability of the different water quality parameters. The resultant maps revealed an important contamination and illustrated that the degree of contamination differs from one site to another, depending on the distance from the pollution source (industrial, domestic or agricultural activity), the depth of the groundwater table and also the maintenance of the well and its surroundings.

Keywords: Sfax; Flood control channel; Water and Sediment quality
\end{abstract}

Submission: April 20, $2014 \quad$ Corrected : May 20, 2014 Accepted: Juny 3, 2014

Doi: $10.12777 /$ ijse.7.1.23-29

[How to cite this article: Dahri , N., Atoui, A. and Abida, H. 2014. Environmental Impact Assessment of a Flood Control Channel in Sfax City, Tunisia, Internat. J. Sci. Eng, 7(1):23-29; Doi: 10.12777/ijse.7.1.23-29]

\section{INTRODUCTION}

Flood represents one of the most serious natural disasters in the world. In Tunisia, floods cause important damages (human and economic losses). During the last forty years, the most important floods have generated 929 victims, 430.000 tramp and loss of 321 million U.S dollars (EMDAT, 2006).

The city of Sfax, Tunisia, located on the south-eastern Mediterranean Sea, is confronted to the effects entrained by important flood risks. Following the 1982 flood event which severely damaged the city, an artificial channel, located $4 \mathrm{~km}$ away from downtown Sfax, was implemented in 1984 to protect the city against floods. Even though it contributed to reduce the harmful flood effects, this channel also resulted in new environmental problems that may cause a public health threat. It increased the severity eutrophication and its toxic effects.

This study is based on the analysis of the physicochemical parameters of water along the channel and several surrounding wells in order to examine the surface water quality in this channel and its relationship with the surrounding groundwater quality. The data sets obtained were subjected to geostatistical analysis to yield the spatial distribution of the examined variables. The obtained maps would help in identifying the origins of water and sediment contamination and to characterize the general environmental state of the channel and its surrounding area.

The city of Sfax, Tunisia, is located on the southeastern Mediterranean Sea and extends between 34 ${ }^{\circ} 49^{\prime}-$ $34^{\circ} 38^{\prime} \mathrm{N}, 10^{\circ} 36^{\prime}-10^{\circ} 52^{\prime} \mathrm{E}$ (Fig.1). Covering $170 \mathrm{~km}^{2}$, this city is considered the second largest city in Tunisia after Tunis (Hamza chaffai et al., 1997; Tayibi et al., 2009) and an important industrial center. Its low topography, disadvantageous geographic location and high population density make it very vulnerable to climate change. Sfax City is characterized by an arid to semi-arid Mediterranean climate, which is the result of the 
convergence of several climatic parameters. Rainfall is variable in time and space, with an annual average value of $222 \mathrm{~mm}$ over a period of 73 years (SERAH, 2012). Average temperature varies from $11.3{ }^{\circ} \mathrm{C}$ in January to $26.5^{\circ} \mathrm{C}$ in August, with an annual average of $19{ }^{\circ} \mathrm{C}$. In Sfax City, the dominant wind is mostly blowing from the south or the south-west known as sirocco. During the fall season, this city is influenced by northerly winds. The study area is situated between the Gremda Road and the southern coastline (Fig.1). It is drained by the southern branch of pk4 channel. The southern branch is the longest artificial channel in Sfax, with a total length of $6,814 \mathrm{~km}$. It is characterized by a relatively stable slope.

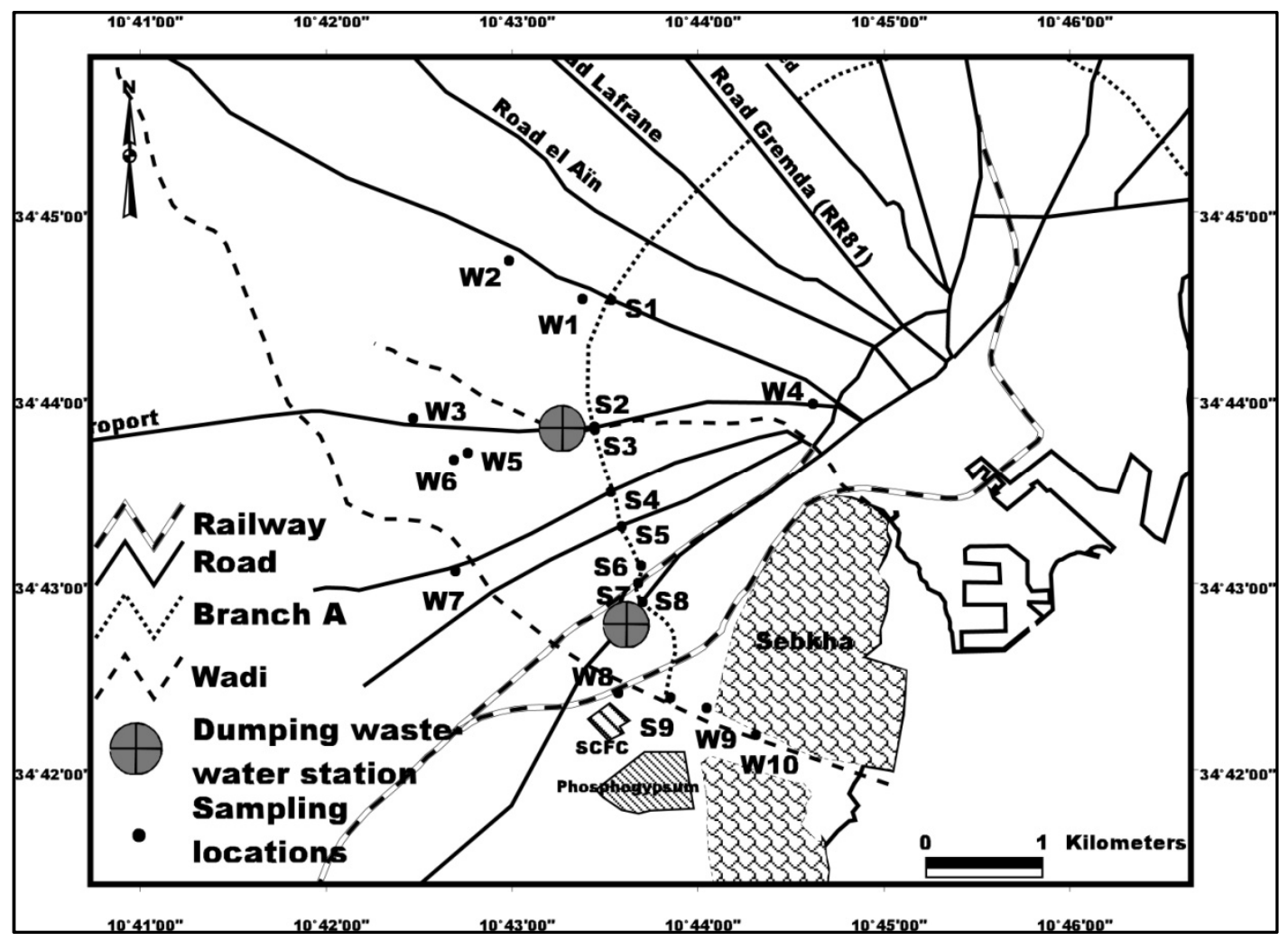

Fig. 1 Study area and sampling point's locations

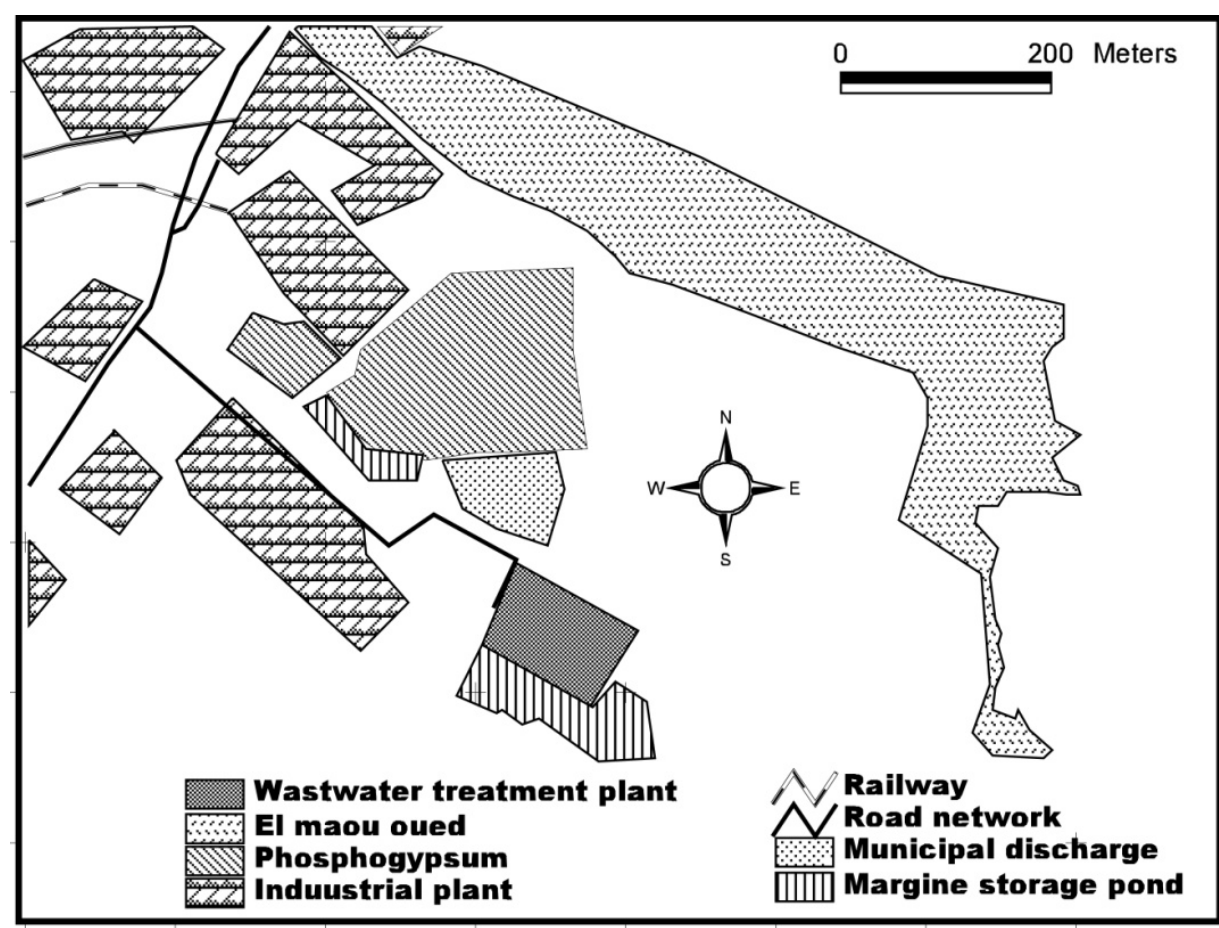

Fig. 2 Industrial areas in the vicinity of the phosphogypsum pile (Sfax City) 


\section{MATERIALS AND METHODS}

\section{A. Sampling and chemical analysis}

Water samples were collected from the channel and close groundwater wells in a dry period (March and April 2013). Water samples were preserved and transported to the laboratory according to standard methods (APHA, 1999). The samples were analyzed for $\mathrm{pH}$, electrical Conductivity (EC), nitrate, ammoniac, chemical oxygen demand, chloride $(\mathrm{Cl})$, sulphate $\left(\mathrm{SO}_{4}\right)$ etc. Major elements $\left(\mathrm{Cl}-\mathrm{SO}_{4}{ }^{2-}\right.$ etc) and heavy metals were analyzed respectively by ion liquid chromatography and polarography methods in the geochemical laboratory of the High Institute of Water Science and Technology of Gabes. All of the parameters were expressed in milligrams per liter $\left(\mathrm{mg} / \mathrm{l}^{-}\right)$, except for $\mathrm{pH}$ and EC $\left(\mu \mathrm{S} / \mathrm{cm}^{-}\right)$. The Sediment samples were analyzed for organic matter concentrations.

\section{B. Data treatment}

\section{a. Geostatistical method}

The kriging method was employed to assess the space variability of water pollution parameters. The method of universal kriging with an integrated linear rift was applied to reconstitute the concentrations of water parameters. Some analytical procedures are further integrated into GIS, turning statistical into geostatistical analysis and adding value to existing datasets by setting spatial context and relationships. This study employed GIS to assign and estimate point and non-point pollution sources in the artificial channel systems.

\section{RESULTS AND DISCUSSIONS}

\section{A. Results}

a. Water quality

A total of 19 water samples were collected in a dry period. Table 1 summarizes briefly the mean value and standard deviation of the 12 measured variables in the channel water samples from the 9 stations and 10 from groundwater wells. It must be noticed that the high dispersion of most variables (high standard deviations) indicates variability in chemical composition between samples. Many of the pollutants parameters examined in the present study exceed regulatory Tunisian standards NT106 (1989). It must be emphasized that average concentrations of some variables such as chloride, sulphate, $\mathrm{NO}_{3}, \mathrm{NH}_{4}$, conductivity, COD, TSS and lead are higher than those recommended by the Tunisian standards.

Data collected in this study were used to develop water quality maps with the kriging interpolation method. The maps generated illustrated and identified the possible pollution origins in the study area. These maps revealed that the data distribution for some parameters was too sparse to examine local differences in concentrations. The water quality maps are presented for the concentrations of the following parameters: suspended solids, nutrients (ammonium, COD), major ions (chloride, sulphate) and trace elements $(\mathrm{Cd}, \mathrm{Pb})$.

- Suspended solids (SS) (Fig.3)

The distribution of the suspended solid concentration values shows a progressive increase in the upstream downstream direction. As indicated in table 1, the suspended solid concentration in the water flowing through the channel is comparable to that found in untreated wastewater. In fact, in most of the stations, the suspended solids concentrations exceed the Tunisian standards $(30 \mathrm{mg} / \mathrm{l})$. The highest content of suspended solid is probably due to the wastewater discharge. Suspended solid originate from many other sources including atmospheric deposition and waste incineration. The highest concentrations of SS occur in the downstream of study area.

The particles with low density remain in suspension. Measured suspended solid concentrations are statistically related to measured turbidity with a correlation coefficient of 0.74 (Fig.4). The linear regression relationship between total suspended solid concentration and turbidity has a slope of (0.73).

The results obtained revealed that the turbidity measurements follow the suspended solid concentration along the channel (Hannouche et al., 2012).

- Ammonium (Fig.5a)

The highest concentrations of ammonium occur in the downstream section of the study area (S7, W10). In fact, the ammonium content ranged from 0.56 (S5) to $13.44 \mathrm{mg} / \mathrm{l}$ (S7) along the channel. However, the ammonium concentrations in the shallow groundwater wells ranged from 0.56 (W7) to $19.04 \mathrm{mg} / \mathrm{l}$ (W10).

- Chloride (Fig.5b)

Chloride is a widely recognized tracer of effluent movement. Chloride concentration varied between 306 (S3) to $3216 \mathrm{mg} / \mathrm{l}$ (S6) along the channel. The highest chloride concentrations in groundwater were observed in the wells of the agricultural area. In general, high concentrations of chloride occur within the central part of the channel and the downstream areas.

- Sulphate (Fig.5c)

Sulphate concentrations show a similar distribution to that of chloride in the study area. The high concentrations of sulphate may reflect a large number of potential sources, including effluents from the major urban areas, agricultural fertilizers, geological sources and atmospheric deposition.

- COD (Fig.5d)

High concentrations of COD arise in the central and downstream areas. COD concentration ranged from 160.6 to $259.2 \mathrm{mg} / \mathrm{l}$ along the channel. In groundwater wells, this concentration varied between 32 and $166.4 \mathrm{mg} / \mathrm{l}\left(\mathrm{O}_{2}\right)$.

- Cadmium (Fig.5e)

The characteristics of the cadmium concentration map show high concentrations of cadmium in the downstream area (industrial residential areas).

- Lead (Fig.5f)

The $\mathrm{Pb}$ concentration reached $0.45 \mathrm{ppm}$ in station (S2). Indeed, the lead content exceeds the standard $(0.1$ ppm) in all stations. 
Table 1. Statistics of water samples characteristics

\begin{tabular}{|c|c|c|c|c|c|c|c|c|c|c|}
\hline \multirow[t]{2}{*}{ Parameters } & \multirow[t]{2}{*}{ Unite } & \multicolumn{4}{|c|}{ The channel Water samples } & \multicolumn{4}{|c|}{ Groundwater samples } & \multirow[t]{2}{*}{ G.C } \\
\hline & & Min & Max & Mean & Std.Dev & Min & Max & Mean & Std.Dev & \\
\hline Chloride & $\mathrm{mg} / \mathrm{l}$ & 305.8 & 3215.7 & 1674.4 & 916.3 & 147.8 & 1312.4 & 703.1 & 443.4 & 600 \\
\hline $\mathrm{NO}^{3-}$ & $\mathrm{mg} / \mathrm{l}$ & 31.6 & 89.2 & 58.8 & 18.3 & 24.9 & 73.68 & 41.3 & 15.6 & 50 \\
\hline SO42- & $\mathrm{mg} / \mathrm{l}$ & 873.2 & 2373.1 & 1645 & 411.6 & 552.5 & 2774.9 & 1514.1 & 692.9 & 600 \\
\hline $\mathrm{CE}$ & $\mu \mathrm{s} / \mathrm{cm}$ & 6170 & 17670 & 10677.8 & 3347.9 & 2930 & 11870 & 6955 & 3075.8 & 7000 \\
\hline $\mathrm{pH}$ & & 6.7 & 8.4 & 7.6 & 0.4 & 7.1 & 7.9 & 7.5 & 0.25 & $6.5<\mathrm{pH}<8.5$ \\
\hline Turbidity & NTU & 1 & 28.4 & 10.8 & 8.5 & 0.14 & 244 & 32.6 & 73.6 & Absence \\
\hline TSS & $\mathrm{mg} / \mathrm{l}$ & 10 & 120 & 42.2 & 31.2 & 10 & 200 & 43 & 57.1 & 30 \\
\hline DCO & $\mathrm{mg} / \mathrm{l}$ & 160.64 & 259.2 & 201.5 & 30.7 & 32 & 166.4 & 126.8 & 37.3 & 90 \\
\hline $\mathrm{NH}^{+}{ }^{+}$ & $\mathrm{mg} / \mathrm{l}$ & 0.56 & 13.44 & 3.5 & 3.6 & 0.56 & 19.04 & 4.3 & 5.34 & 1 \\
\hline Lead & ppm & 0.17 & 0.45 & 0.3 & 0.08 & 0.13 & 0.26 & 0.2 & 0.035 & 0.1 \\
\hline Cadmium & ppm & 0 & 0.007 & 0.002 & 0.002 & 0 & 0.009 & 0.002 & 0.003 & 0.005 \\
\hline
\end{tabular}

(*) Recommended standards allowed by the Tunisian Directive NT 106.02 (1989) of the water quality in the urban public sector.

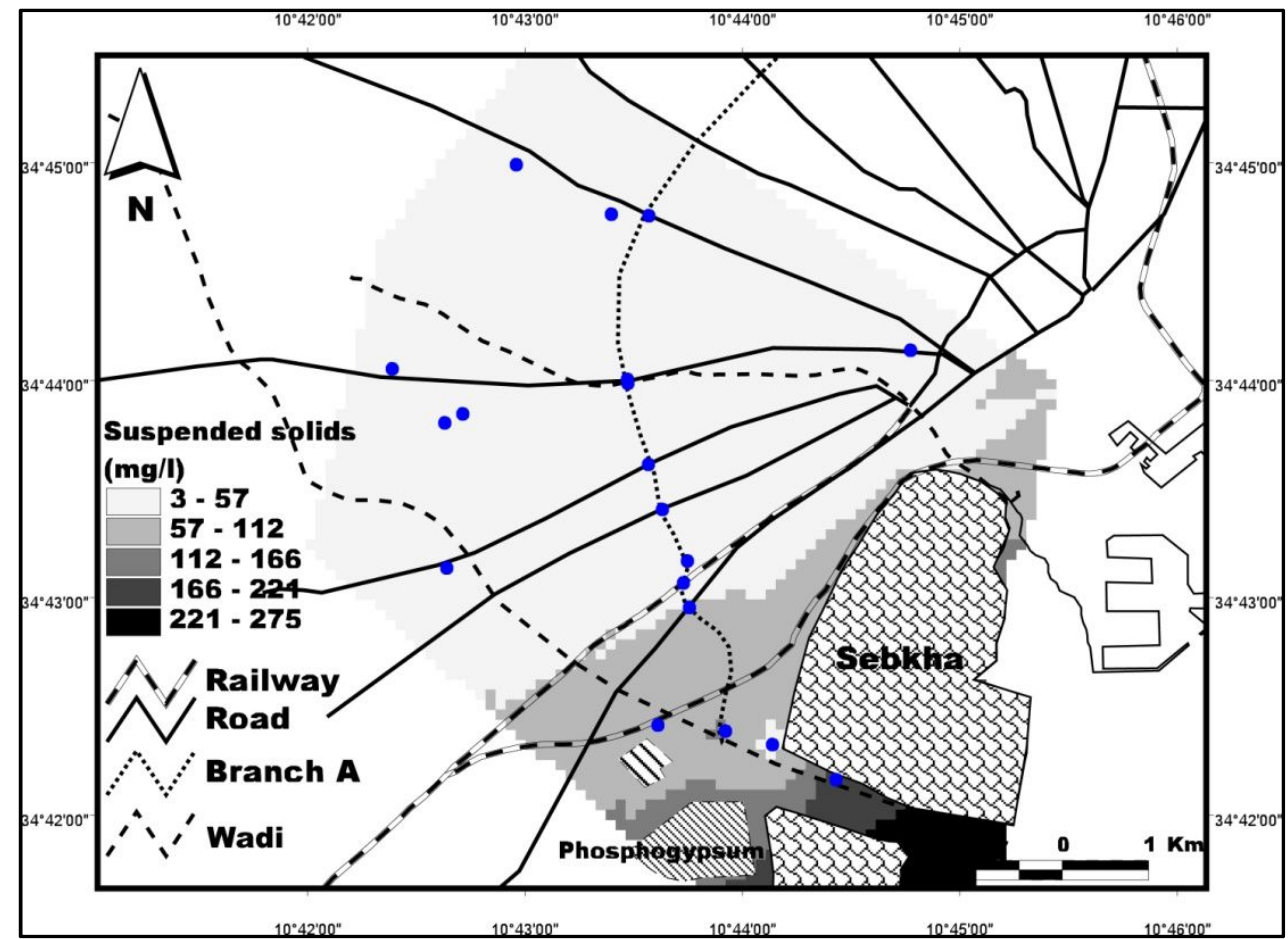

Fig. 3 Map of suspended-solid concentrations

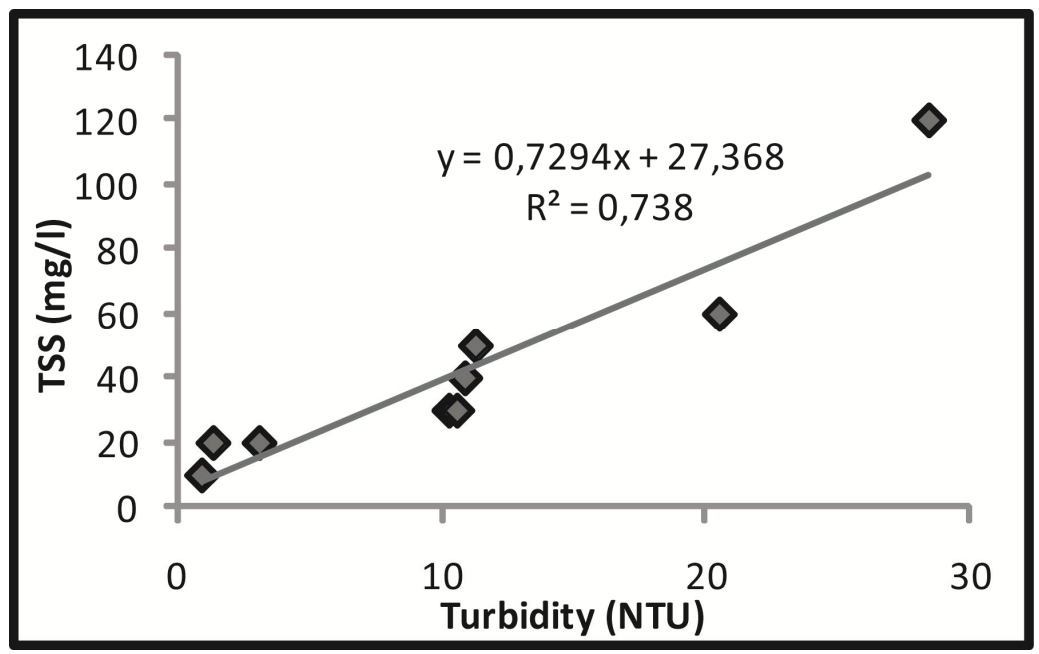

Fig. 4 The linear regression relationship between total suspended solid concentration and turbidity 


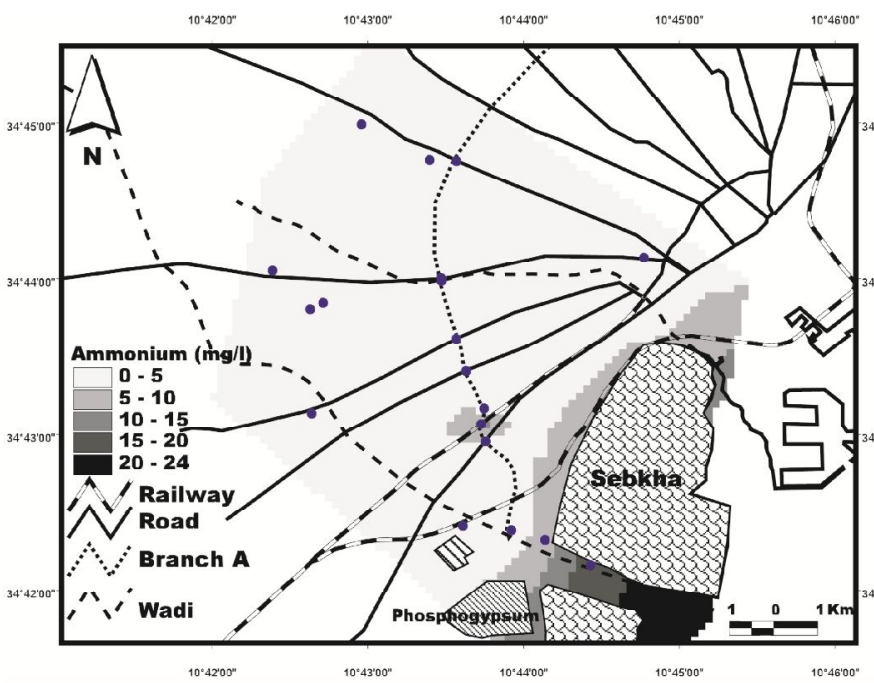

a. Ammonium concentration

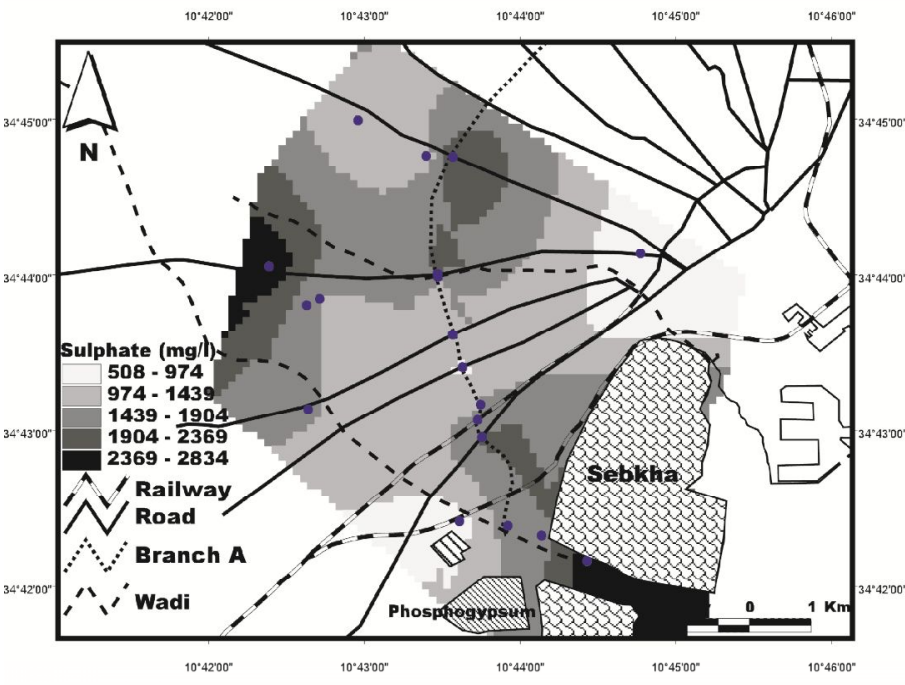

c. Sulphate concentration

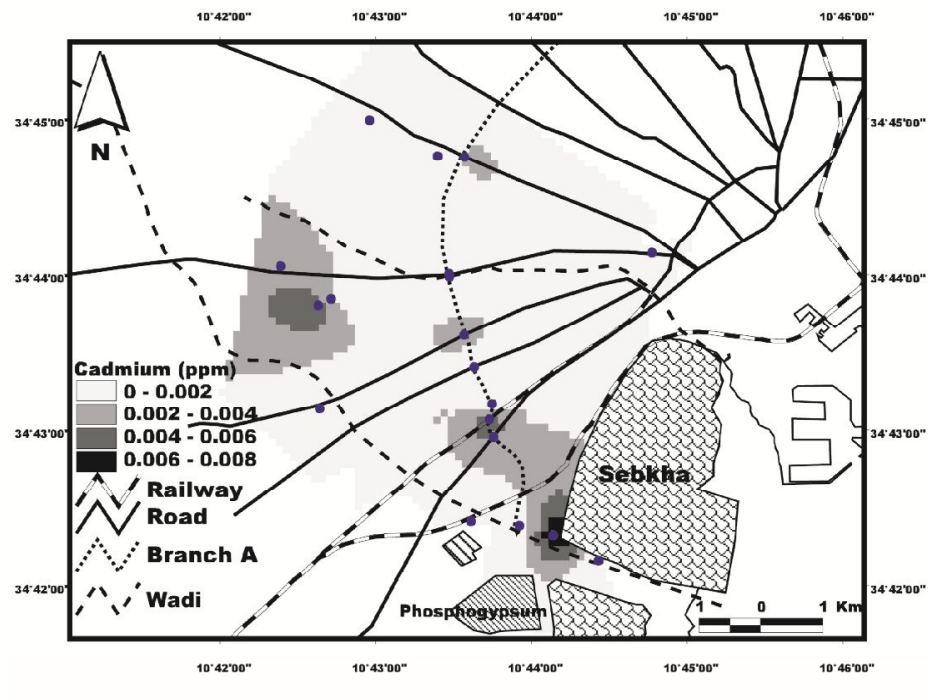

e. Cd concentration

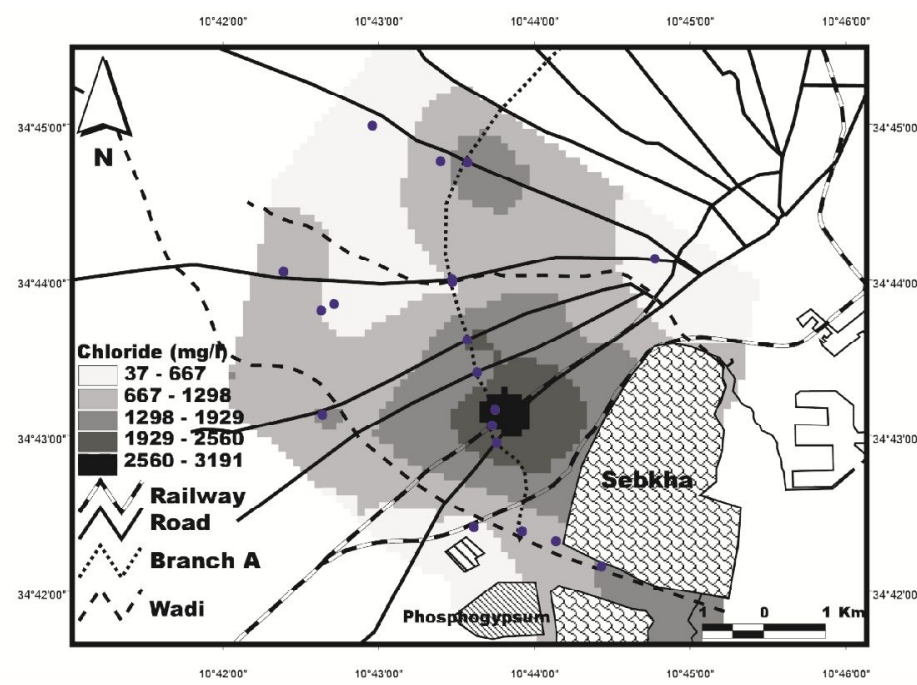

b. Chloride concentration

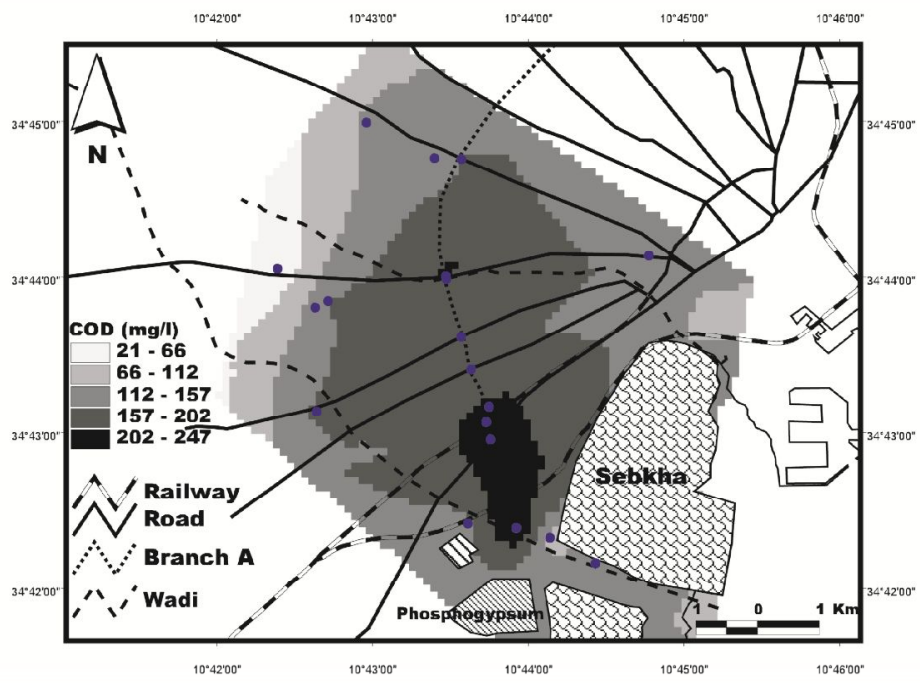

d. COD concentration

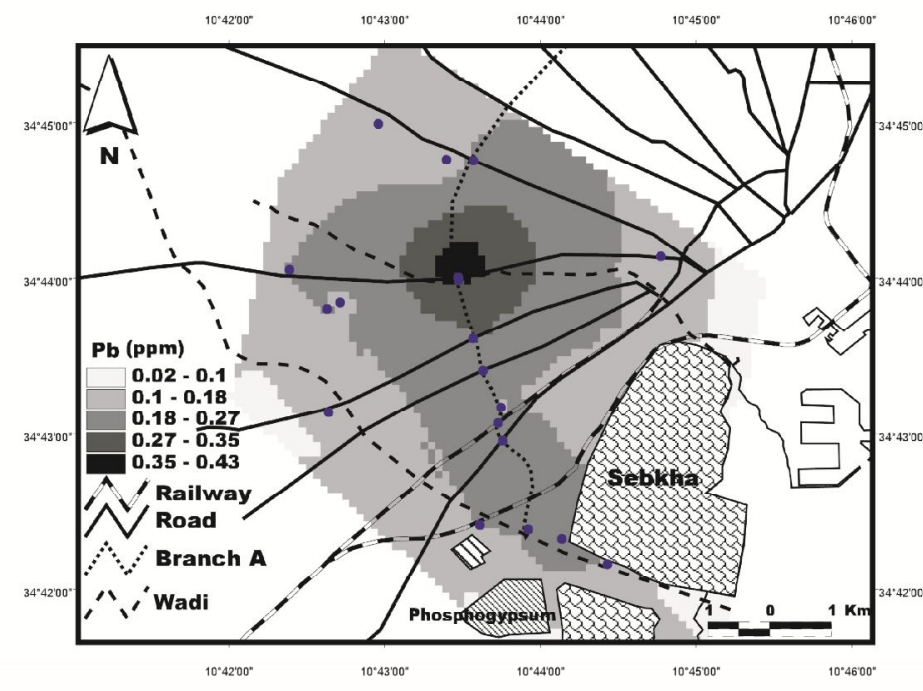

f. Pb concentration

Fig. 5 Spatial distributions of water quality data 


\section{a. Sediment quality}

- Organic matter concentration (Fig.6)

Sediment samples were collected from the bottom of the channel (starting from the road Gremda). The results obtained show that concentration of organic matter fluctuates between $1.4 \% \quad$ (SS4) and $11.5 \% \quad$ (SS12). Generally, the organic matter concentration increased in the upstream to downstream direction. The highest concentrations of organic matter occur downstream of the study area.

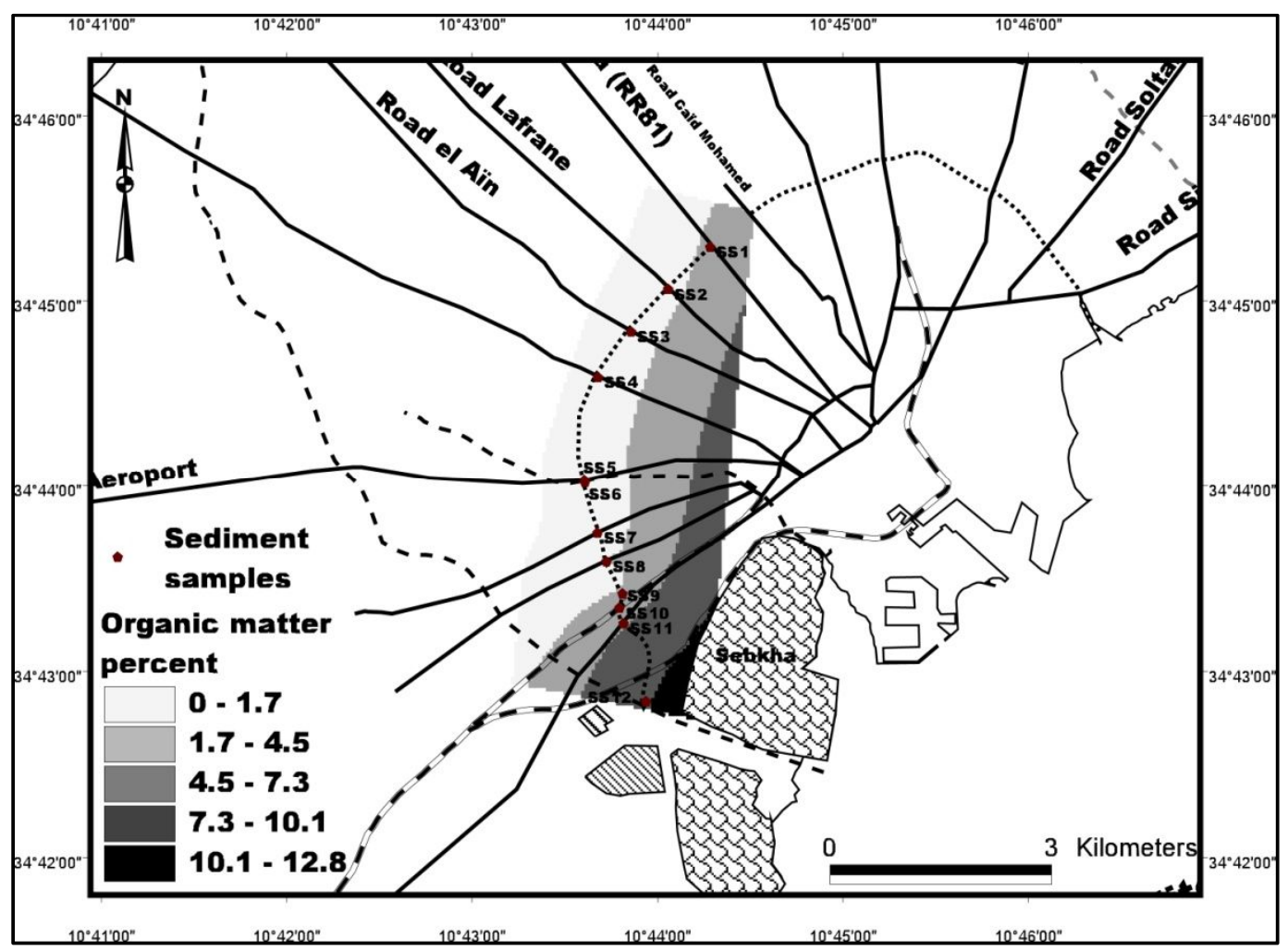

Fig. 6 Organic matter percent in the sediment samples along the pk4 channel

\section{B. Discussion}

The chemical and organic concentration maps show a high variability in water quality. High concentrations of the different water quality parameters were observed in the large industrial urban areas (near the phosphogypsum dump), the agriculture area (W3 and W7) and near the wastewater pumping station (Jarvie et al., 2000). The high concentrations within these areas can be attributed to groundwater quality (Chamtouri, 2007) which has been found to have a major impact on channel water quality. More detailed results are discussed in the following sections related to: trace metals and suspended solids (1), organic parameters (2) and major ions (3).

- Trace metals and suspended solids

Most of the trace metals show very high concentrations clustered in the channel which drains the contaminated groundwater. Cadmium and lead exhibit particularly high concentrations in the southern area relative to the rest of the study area, and have a primarily industrial, automobile and agriculture sources. High Cadmium concentrations occur within the industrial areas, suggesting that the percolation in the phosphogypsum pile (figure 11) carry the contaminants to the surrounding groundwater in the downstream area. The storage of phosphogypsum without any prior treatment requires large land areas and can entrain serious environmental contamination to soil, water and the surrounding environment. The highest concentrations of $\mathrm{Cd}$ in the groundwater well (W6) can be explained by the low maintenance of this well. Regarding the concentration of lead in contaminated water (from the channel and groundwater), it can be generated from a wide variety of anthropogenic sources such as Traffic automobiles, agriculturale, fumes and industrial sources. Cadmium and lead have high concentrations, and show a similar distribution to suspended solids in the downstream zone. These trace elements are therefore predominantly carried in particulate form and are thus subject to sediment transport effects. The suspended solids can be attributed to the wastewater discharge and the anthropogenic dry and wet particulate deposition from industries such as the Sfax chemical fertilizer company.

The highest concentrations of organic matter in the sediment samples along the channel occur in the downstream part of the study area. This can be explained by the wastewater discharge, which represents the main and nearly constant source of organic matter (SS6, SS9, SS10, SS11 and SS12) into pk4 channel. Furthermore, the flow rate decreases decantation along the channel. COD and ammonium are related to organic pollution. Their profiles in water samples are similar to organic matter concentration in sediment samples. The organic matter analyzed in sediment samples confirmed the contamination of this environment. This spatial pollution pattern is possibly related to the topography and the dominant wind direction in Sfax. 
- Chemical demand oxygen, nitrate and ammonium

The highest concentrations of COD at the outlet of the channel can be explained by the groundwater quality and the effluent inputs. In fact, the groundwater analysis shows a global chemical homogeneity with a sulphated sodic facies and an enrichment of chloride. This result is similar to that found by Chamtouri et al, (2007). The major sources of COD in urban area are the discharge of industrial and waste domestic water.

Ammonium exhibit high concentration near the Sfax chemical fertilizer company. Obviously, the gaseous emissions from the production of ammonium phosphate fertilizer represent the major origin of this concentration. Moreover, groundwater contamination by nitrogen compounds is the origin of the surface water quality deterioration along the channel. The highest concentrations were registered in the northern area, where the sanitary sewer system is not well developed (S1, W1 and W2).

The major impact associated with nutrient (ammonium and nitrate) over enrichment is excessive growth of algal that leads to nuisance algal blooms and eutrophic conditions.

- Major ions

Generally, Electrical conductivity which exceeds the standards in most of the stations $(7000 \mu \mathrm{S} / \mathrm{cm})$ revealed a contamination of water samples (table1). Chloride and sulphate are abundant in groundwater and therefore show very high concentrations in the channel. High chloride concentrations were also observed in stations S1, S6, S7 and S8. High chloride concentrations can be attributed to wastewater discharge and saline groundwaters. The high sulphate concentrations in well W3 are related to agricultural fertilizers. The high concentration of sulphate and chloride concentrations in the study area reflect a large number of potential sources, including effluents from the major urban area, agricultural fertilizer, geological sources and atmospheric deposition.

\section{Conclusions}

In this study, spatial variability maps of water quality data were developed to identify the potential origins of pollution. This study has demonstrated the importance of anthropogenic influences along the channel. These anthropogenic influences are dominated by effluent inputs in the central reach of the channel, which appear to be strongly linked to increased concentrations of suspended solids, trace metals and organic matter.

The results of the water analysis demonstrate that water deterioration in the channel is related firstly to contaminated groundwater drained by the channel and secondly to anthropogenic inputs. The groundwater chemistry indicated that the chemical facies of the examined groundwater is sulphated sodic, with an enrichment of chloride.

Variables, which distributions are not directly related to geological controls, are subject to anthropogenic activity. Particularly, the distribution of the suspended solid, nutrient and organic element concentration (COD, $\mathrm{NH}_{4}, \mathrm{NO}_{3}, \mathrm{OM}$, etc.) revealed that this channel is affected by direct input of various contaminants. High nitrate concentrations are attributed to the continuous injection of untreated domestic wastewaters via recharge wells.

Cadmium and lead have high concentrations in the downstream zone. These concentrations confirm the source of contamination to be anthropogenic industrial activities, which have led to contamination of water and sediment in this area. With regard to the sources of the chemical parameters, three broad types characterize the patterns observed. These types are as follows:

- Type A (SS, COD, $\mathrm{NH}_{4}, \mathrm{Cd}$ and $\mathrm{Pb}$ ): effluent and anthropogenic inputs from urban centres.

Type $\mathrm{B}\left(\mathrm{NH}_{4}\right.$ and $\left.\mathrm{NO}_{3}\right)$ : effluent inputs from urban centres, groundwater flow and agricultural runoff.

- Type C (major ions): effluent inputs from urban centres and bedrock.

\section{REFERENCES}

[1] APHA, 1999. Standard Methods for the examination of Water and Wastewater. 19th Edition, American Public Health Association, Washington, D.C.

[2] Barroca, B., Bernardara, P., Mouchel, J.M., Hubert,G., 2006. Indicators for identification of urban flooding vulnerability. Nat. Hazards Earth Syst. Sci.6, 553-561.

[3] Chamtouri, I., Abida, H., Khanfir, H., Bouri, S., 2007. Impacts of at-site wastewater disposal systems on the groundwater aquifer in arid regions: case of Sfax City. Southern Tunisia. Environ Geology. No 55: 1123-1133p.

[4] EMDAT, 2006. Base de données International sur les catastrophes naturelles de OFDA (Agence des Etat Unis pour le développement international)/ CRED (Centre pour Recherche sur Epidémiologie des catastrophe), Université catholique de Louvain - Bruxelles - Belgique.

[5] Hamza-Chaffai, A., Pellerin, J., Amiard, J.C., 2003. Health assessment of a marine bivalve Ruditapes decussatus from the Gulf of Gabès (Tunisia). Environment International 28, 609-617.

[6] Hannouche A., Chebbo G., Ruban G., Tassin B., Joannis C., 2012. Relation entre la turbidité et la concentration en matières en suspension en réseau d'assainissement unitaire. Techniques Sciences Méthodes 2010. 42-51.

[7] Jarvie,H.P., Oguchi, T., Neal, C., 2000. Pollution regimes and variability in river water quality across the Humber catchment: Interrogation and mapping of an extensive and highly heterogeneous spatial dataset. Sci. Total Environ. 251/252, 27-44

[8] Zairi, M., Rouis, MJ., 1999. Impacts environnementaux du stockage du phosphogypse à Sfax (Tunisie). Bulletin des laboratoires des ponts et chaussées. 29-40. 